\title{
Design of Work Instruction (WI) Electronic Workbench-Assisted Electrical Measuring Devices to Improve the Internship Concept of Students in Basic Electronic II Course
}

\author{
Islahudin ${ }^{1}$, Johri Sabaryati ${ }^{2}$, Zulkarnain ${ }^{3}$, Soeharto ${ }^{4}$ \\ University of Muhammadiyah Mataram, Indonesia ${ }^{1,2,3}$, University of Szeged, Hungary ${ }^{4}$ \\ islahudin.ntb@gmail.com ${ }^{1}$, joyafarashy@gmail.com² ${ }^{2}$ dzul9787@gmail.com³, \\ soeharto.soeharto@edu.u-szeged.hu ${ }^{4}$
}



\author{
Keywords : \\ Work Intruction; Electronic \\ Workbench; Basic Electronic
}

\begin{abstract}
Basic electronic II course must be supported by softwarebased virtual laboratory, one of which is to design work instructions (WI) of electrical measuring devices. The objectives of this research was to determine the extent of the influence of the design of work instruction (WI) electronic workbench-assisted electrical measuring devices on improving the internship concept of students in basic electronic II course. The sampling technique waspurposive sampling. The population of this research were all physics studentFaculty of Training Teacher and Education University of MuhammadiyahMataram. The research sample was a class of 2018 students who were took Basic Electronic II course. The research design used was one group pre-test post-test design where the sample was given a pre-test (initial test) before the first treatment and a posttest (final test) at the end of learning. The data analysis technique used was pre-test and post-test with the influence test formula or the t-test at a confidence level of $95 \%$. The improvement in understanding of the internship concepts before and after using work instructions (WI) was calculated using the normalized reinforcement test $(N$ Gain). The result showed the $t_{\text {count }}(=5,017)>t_{\text {table }}(=2,365)$ was at a confidence level of $95 \%$, so that the alternative hypothesis $\left(H_{a}\right)$ was accepted. The improvement in understanding of the internship concept using work instructions (WI) ElectronicWorkbench-assistedelectrical measuring devices was indicated by $N$-Gain of 0,441, so that it lies in the medium category. Based on the results of the research, it can be concluded that there was a significant influence on the use of the design of work instruction (WI) electronic workbench-assistedelectrical measuring devices on improving of the internship concept of students in the Basic Electronic II course.
\end{abstract}




\section{INTRODUCTION}

The era of digitization leads to all aspects of life with energy and electrical devices. Because the use of power tools is very helpful to make all human work easier. One of the main subjects for understanding and using electrical devices is the Basic Electronic II course.

The Basic Electronic II course is one of the most important subjects in physics studies. Cause it is the amount of electricity that is obtained by measurements with electrical measuring devices. An electrical quantity can be measured correctly if the electrical measuring device used, including the processing of the measurement results, can be used correctly.

The observation results of the learning outcomes of physics students in the past year show that the value of basic electronic courses is relatively low on average. Learning outcomes of the students on the quiz average of 29.9 and below the pass mark of 70 and very far from the pass mark of 70 . This happens because at the time of the practical activities, the pupils do not know how to operate electrical measuring devices correctly and correctly when measuring electricity. This also happened because the factorymade manual for the use of electrical measuring devices was not understood in advance. The manual for the use of electrical measuring devices must first be understood before the tools are operated.

To make it easier for students to understand the use of electrical measuring instruments, the researchers draft work instructions (WI) for each electrical measuring device in the electronic laboratory of the study programs for physics lessons for which no electrical measuring devices have been available in the past 6 years. The work instructions are designed with a focus on creative and innovative principles [1]. In addition, the WI to be designed is equipped with laboratory software from the Virtual Electronic Workbench (EWB). The existence of a WI integration with the help of EWB software is likely to be very interesting and useful for students later, since work instructions can first be practiced directly in a simulation. Students are expected to have a good understanding of the basics before making actual measurements using electrical circuitry.

The EWB (Electronic Workbench) software is a software for electronicfrom Interactive Image Technology Ltd. Electronic Workbench as shown in Fig. 1.

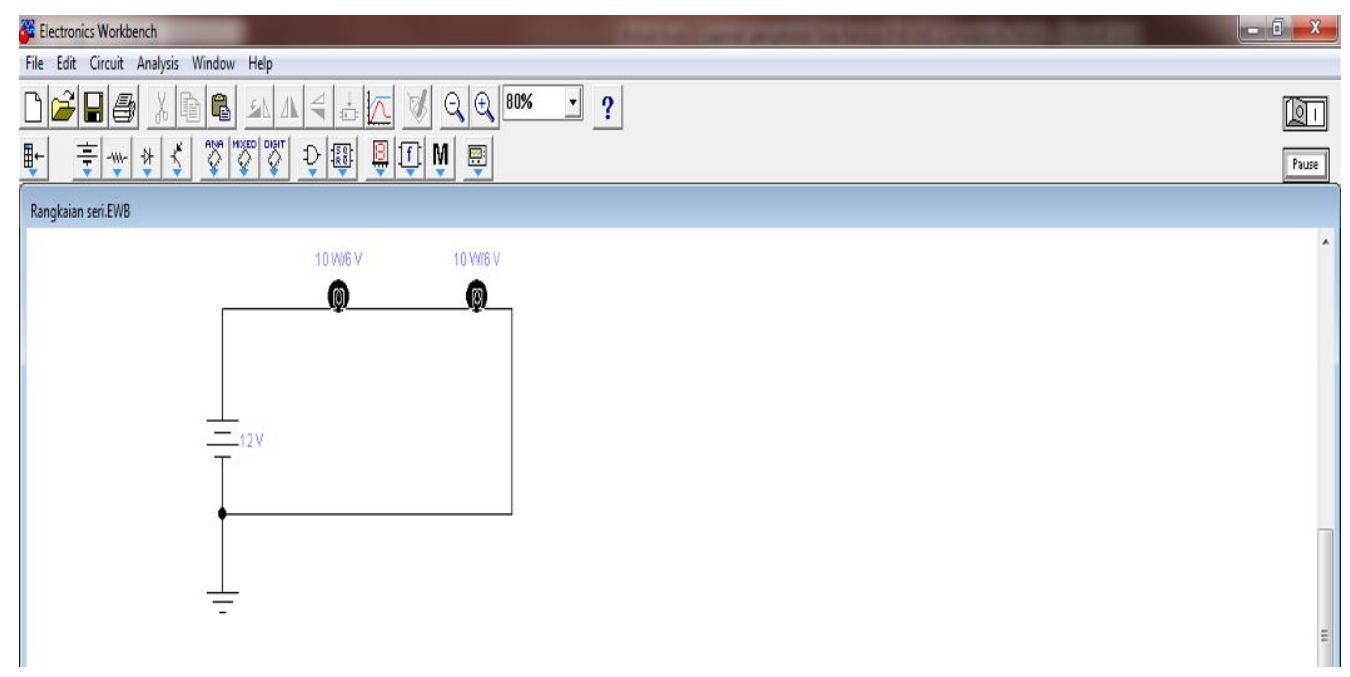

Fig 1. The Series Conjunction using EWB.

There are various tools inElectronic Workbench with which electrical circuits can be converted into digital or analog systems [2]. With a standard simulator and a high level of software integration consisting of circuit diagram editors, SPICE simulators and screen waveforms, using the Electronic 
Workbench is so easy. Based on Figure 3, it seems that learning by simulating students and teachers doesn't need to spend a lot of time and money to buy ICs or other required components. Just sit down sweetly on the computer. You don't have to solder so that no time is wasted. You don't have to buy measuring instruments because everything is available in the simulation. In addition, students and even teachers can learn to place circuits anywhere, anytime, as they are no longer constrained by the lack of electrical kits or lab rooms. However, this does not necessarily make students and teachers lazy to work on an electronic project or circuit in the laboratory. Because direct practice has a different taste than just simulations. It can be concluded from this that EWB is software that can be used to overcome the problem of the lack of electrical equipment in the laboratory, so that it can be used by both students and students [3].

The laboratory is a specific place or space that is equipped with equipment for carrying out experiments (examination, etc.). The laboratory is one of the most important components in realizing the function of higher education. The laboratory is a facility for students and faculty to conduct educational activities, research and community services [4]. By using laboratories as a means of carrying out educational activities, research and services for the community, the laboratory is equipped with facilities and infrastructures that are good and meet the standards so that laboratory activities run smoothly and optimally. Laboratory work instructions were compiled to improve management and work guidelines [5]. Tool work instructions that contain the correct use of the tool are created in such a way that the service life is longer. Work instructions include information about the specifications of the tool, the function of the tool, and how to use the tool to make it clearer. Work instructions are aimed at all laboratory users from internal and external parties. The tool's work instructions better perform laboratory activities related to the use of the tool. With written form and effective communication, the user can better understand the content of the tool's work instructions and improve students' skills in using the tool [6].

Laboratories that implement ISO 17025 must have documentation on the laboratory management system. The documentation hierarchy of the laboratory management system based on SNI ISO / IEC 17025: 2008 consists of 4 types of documents, namely quality guidelines for level 1 documents, level 2 process documents, level 3 work instruction documents and level 4 form documents (BSN, 2015) [7]. Design Research conceptual worksheets for photoelectric effect material for students with Design Research creates a product in the form of worksheets to construct student concepts for the photoelectric effect so that students understand the effect of wavelength on the photoelectric effect and the effect of the type of metal used to understand the wavelengths when the photoelectric effect occurs. After validation by experts who evaluate the content and user interface, the developed product is tested on the user to find the practical and attractive answers. The product receives an assessment with good criteria from the teacher and the pupils, is declared practical for learning and arouses the interest of the teacher and the students [8].

To avoid duplication, the researcher followed previous studies and received various issues related to the problem under investigation, namely, "The impact of application of work instructions on the ability to use equipment in the laboratory of the Tarbiyahand Teaching Faculty in UINSunanAmpel Surabaya ". Obtained $\mathrm{z}$ value of 5,769 and greater than the critical value of $\mathrm{z}(1,645)$. This shows that the application of the tool's work instructions affects the ability to use tools in the Tarbiyah and teaching faculty at the UIN SunanAmpel Surabaya [3]. The research entitled "Developing Conclusions and Communicating the Concept of Physics through Simple Internships in Physics". The results showed that the classic completeness of the final abilities was $69.44 \%$ in the first cycle, $83.33 \%$ in the second cycle and $88.89 \%$ in the third cycle. The results of the classic championship skills communicated in cycle I were $77.78 \%$, in cycle II $88.89 \%$ and in cycle III $94.44 \%$. It can be concluded that simple practical exercises in fluid mechanics can improve the ability to complete and communicate the concepts of physics [9]. On this basis, the researchers conducted researchon the design of work instructions (WI) electronic workbenchassisted electrical measuring devices on improving the internship concept of students in Basic Electronic II course. 


\section{METHOD}

The researchwas the pre-experimental method. According to Sugiono [10], pre-experimental research results are dependent variables that are not only influenced by independent variables.

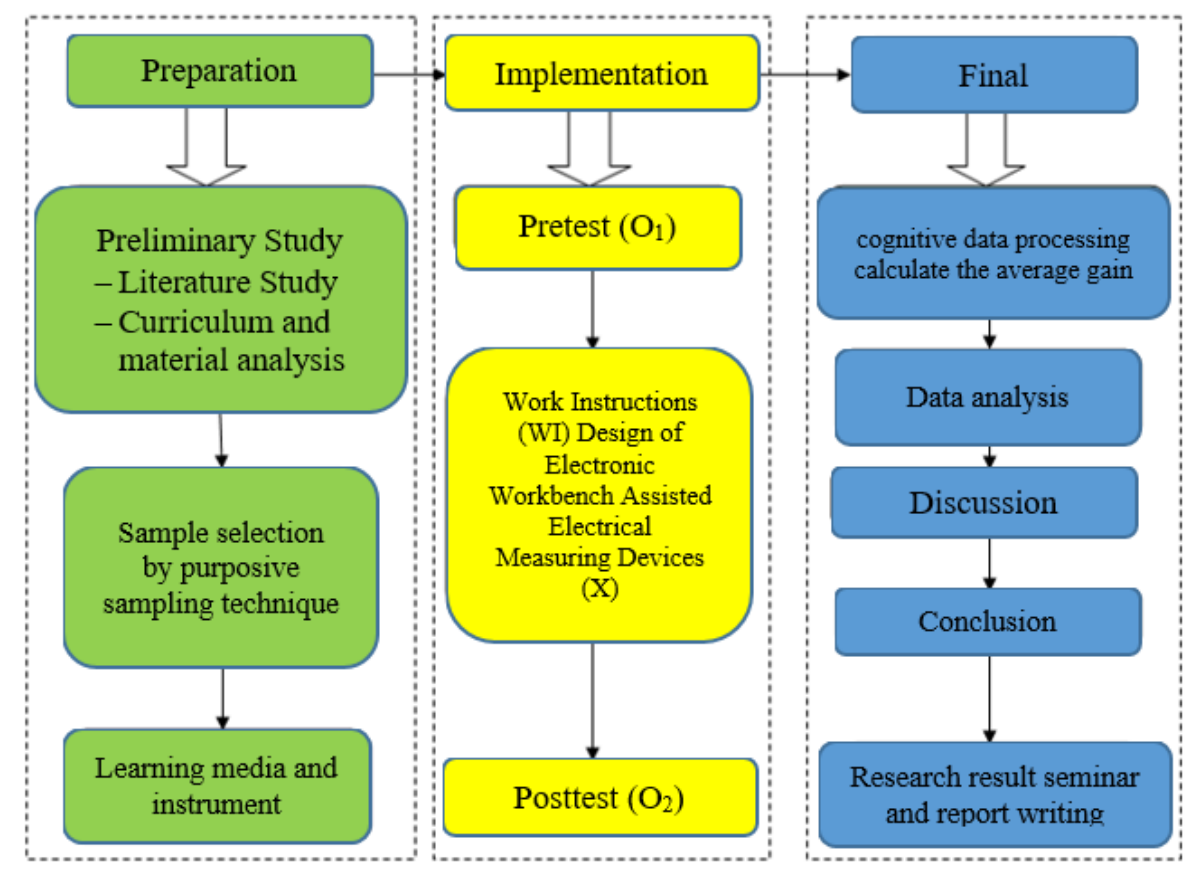

Fig 2. The Research Flow

This happens because there is no tax variable and the sample is not chosen at random. The research design used in this researchwas a one group pre-test post-test design. With this design, the sample is given a pre-test (initial test) before the first treatment and a post-test (final test) at the end of learning. This design was used in accordance with the goals to be achieved that wasto find out the extent of the influence of the design of work instructions (WI) electronic workbench-assisted electrical measuring device on improving of the internship skillof students in basic electronic II course. The following is a one-group pre-test post-test research design according to Table 1.

Table 1. The Research design isone group pretest-posttest design

\begin{tabular}{ccc}
\hline Pretest & Treatment & Posttest \\
\hline $\mathrm{O}_{1}$ & $\mathrm{X}$ & $\mathrm{O}_{2}$ \\
\hline
\end{tabular}

Remarks:

$\mathrm{O}_{1}$ : Pretest before treatment

$\mathrm{O}_{2}$ : Posttest after treatment

$\mathrm{X}$ : The Experimental Group

The subject of the researchwere the students in even academic year 2019/2020. At January to April 2020, this research was carried out. With the population consisted all of students Physics Education Department Faculty of Teacher Traning and Education University of MuhammadiyahMataram. The sample of this research was the classes 2018 with a total of 8 students who were took Basic Electronis II course. 


\section{The Research Flow}

This research flow consist of 3 phases, it was the preparation phases, the implementation phases and the final phases. Those steps research can be seen at Fig 2. Data on student learning outcomes obtained through the production of research tools. The steps to develop the research instrument were as follows:

\section{Data Acquisition Techniques}

The data acquisition was carried out with test instruments. It used a practical test. The aim is to measure the cognitive and psychomotor areas of students at the level of understanding. According to Nurkancana, understanding is the ability to understand all of the learned knowledge, for example the ability to express, compare, interpret, and so on, with other sentence structures. The questions used in the first test are the same as the questions used in the last test. This was to prevent instrument differences from affecting changes in student learning outcomes. There were 10 practice exams used in this research.

\section{Data Analysis Techniques}

Before the instrument was used in the research, it was first validated by other physics lecturers using expert validation [11-12]. The instrument was processed and analyzed after validation. In order to find out the improvement of the practical skills of the students in basic electronic, this is done by analyzing the normalized gain score $\langle\mathrm{g}>$ proposed by Hake (1998) with the formula:

$$
<g>\frac{T_{2}-T_{1}}{T_{m a k s}-T_{1}}
$$

With $\langle\mathrm{g}\rangle$ is the normalized gain score, $\mathrm{T}_{2}$ is the post-test score, $\mathrm{T}_{1}$ the pretest score. Good learning if the normalized score gain is greater than 0.4 . The normalized gain score results are divided into three categories, as shown in Table 2.

Table 2. The Normalized Gain Category

\begin{tabular}{cc}
\hline Percentage & Category \\
\hline $0,00<<\mathrm{g}><0,30$ & Low \\
$0,30<<\mathrm{g}><0,7$ & Medium \\
$0,70<<\mathrm{g}><1,00$ & High \\
\hline
\end{tabular}

To find out the improvement inunderstanding internship concept using work instructions (WI), then the t-test formula was used with the following hypothesis: $\mathrm{H}_{0}=$ there is no significant influence on the use of the design of work instruction (WI) electronic workbench-assistedelectrical measuring devices to improve the internship concept of students in Basic Electronic II course, $\mathrm{Ha}=$ there is asignificant influence on the use of the design of work instruction (WI) electronic workbench-assisted electrical measuring devices to improve the internship concept of students in Basic Electronic II course. The t-test equation (t-test) used in the significance of cycle I and II uses equation [13]:

$$
t=\frac{M_{D}}{\sqrt{\frac{\sum x^{2} d}{N(N-1)}}}
$$

Remarks:

$\mathrm{d}_{\mathrm{i}}=$ diference of post test score and pre-test score of each subject (i)

$\mathrm{M}_{\mathrm{D}}=$ Mean ofGain (d)

$\mathrm{x}_{\mathrm{d}}=$ The deviation of Gain Score against the mean $(\mathrm{xd}=\mathrm{di}-\mathrm{Md})$

$\mathrm{x}^{2} \mathrm{~d}=$ Square of thegainagainst the main

$\mathrm{N}=$ Number of sample (research subject) 


\section{RESULTS AND DISCUSSIONS}

\section{Preliminary study}

This research has been carried out four times using online or online lecture systems. The LMS (Learning Management System), which was used as an application in the form of schoology.

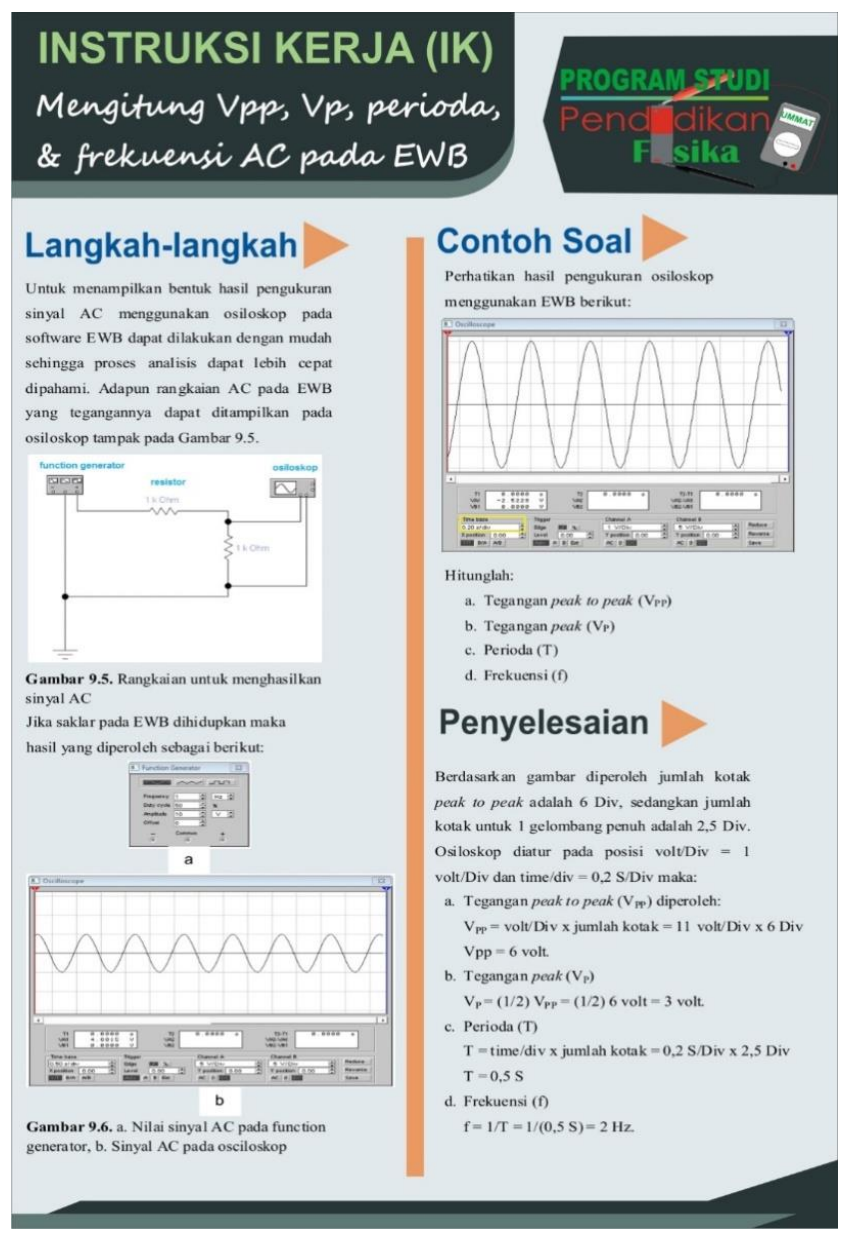

Fig 3. The Work Intruction Counting $V_{P P}, V_{P}$, Period and frequency at EWB

Lecture activities in the first two sessions with the method of learning from discussion and questions and answers at the same time under preliminary examination. In addition, the last two sessions of the lecture were subjected to a post test using work instructions (WI) of electrical measuring device. The learning outcomes of the Basic Electronic I course in Odd 2019/2020 were previously relatively low. This is due to the lack of learning media that support the learning process related to electrical measuring devices, especially virtual laboratories. There are also practical activities that were carried out only twice in a semester, so that the memory of the students is reduced.

\section{Implemention Research}

Learning in Sessions I and II were implemented using the discussion method and the question answer. The basic electronic I material that have discussed is alternating current in a series circuit [14-15]. The learning restrictions are the ineffective methods of its was insufficient time allocation due to the online lecture system, which was first used by students due to the outbreak of the 2019 coronavirus (covid-19). At the end of the second meeting, the researchers gave a quiz question as a pre-test to find out how well the students' concepts were understood. The results of the pre-test are shown in Table 3. Based on Table 3 , it appears that the average results of the pretest have a lower value than the posttest. 
At sessions III and IV, researchers and students agree on the implementation of basic electronic IIlearning, which was carried out using the work instructions (WI) of the integrated electronic workbench (EWB) software, with each student using the software on their respective laptops installed. The wrong form of it media designed in this study is shown in Fig. 2.

Based on Fig. 3, the information can be obtained that the compiled work instruction (WI) is divided into two parts, Were the section steps and example problems. The Steps section contains steps to operate an electrical meter, one of which is in the form of an oscilloscope, while the Sample Problem section contains calculations of measurement results for electrical meters that are accompanied by their completion [16-17].

The material for the third and fourth sessions is the alternating current in the series and parallel connection [18-19]. The learning method used is a practical method in which the EWB (Electronic Workbench) software is used online. Learning activities conducted with an explanation using the Electronic Workbench (EWB) asking each student questions, including oscilloscope calibration, calculation of $\mathrm{Vpp}$ (peak to peak voltage), peak voltage (peak voltage), AC signal period and AC signal frequency. At the end of the IV meeting, the researcher gave a quiz question and a post test. The post test results are shown in Table 3. Based on Table 3, it appears that the average post-test results are higher than the pre-test value.

Table 3. Understanding Internship Concept of Students Before and After Using Work Intructionts

\begin{tabular}{cccc}
\hline Category & Before Using WI & After Using WI \\
\hline The Lowest Value & 10 & 40 \\
The Highest Value & 60 & 80 \\
Average & 26.25 & & 58.75 \\
$\mathrm{~T}_{\text {table }}$ & & 2.363 & \\
$\mathrm{~T}_{\text {count }}$ & & 5.017 & \\
\hline
\end{tabular}

Based on Table 3, the value of $t_{\text {count }}(=5,017)>t_{\text {table }}(=2,363)$ is at the $95 \%$ confidence level. This shows that the alternative hypothesis (ha) is accepted, so that "there is a significant impact on the use of the work instructions (WI) for electrical meters assistedby Electronic Workbench to improve the concept of student internship in basic electronic subjects ".This shows that in addition to the cognitive aspects, the use of work instructions (WI) of the electrical measuring device with Electronic Electron Workbench (EWB) has a positive effect on the psychomotor aspects of the students. Table 3 above, if it was created in graphical form, appears in Fig. 3.

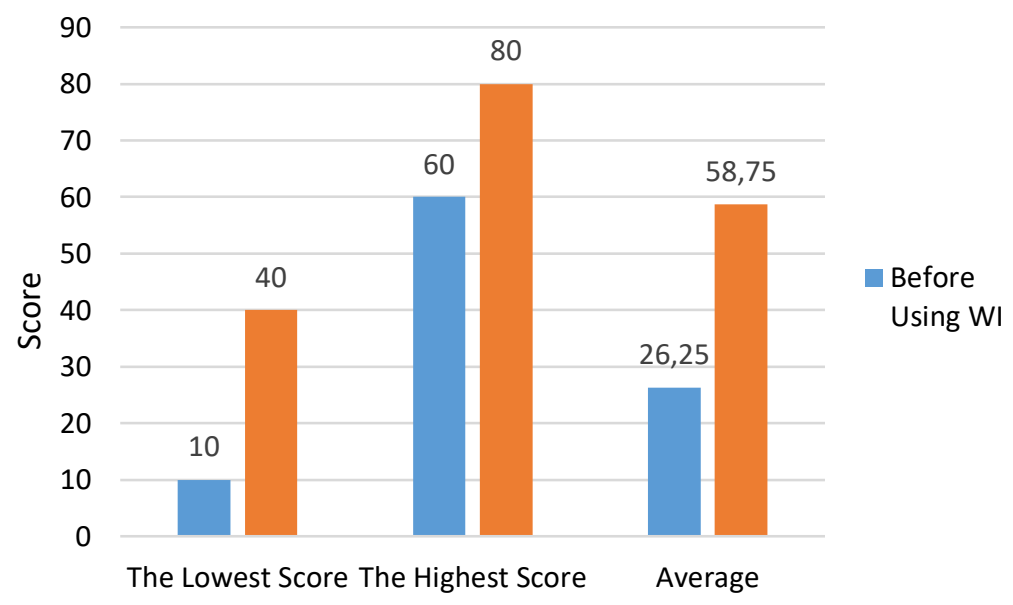

Fig 3. Improvement inUnderstanding Internship Concept of Students. 
Based on Fig. 3 above, a calculation is performed using the N-Gain analysis to find out an improvement in the understanding internship concept of students. The results are obtained as follows.

$$
\begin{aligned}
\text { indeks gain } & =\frac{\text { posttestscore }- \text { pretest score }}{\text { maksimum score }- \text { pre test score }} \\
& =\frac{58.8-26.3}{100-26.3}=0,441
\end{aligned}
$$

Based on Table 3 and in accordance with the results of the above N-Gain calculation, the information is obtained that the understanding internship concept of students in the Basic Electronic II coursewas improved after using the work instructions (WI) in the category medium.

\section{CONCLUSION AND SUGGESTION}

\section{Conclusion}

Based on the result of the research, it can be concluded that there is a significant influence on the use of the design of work instruction (IK) electronic workbench-assisted electrical measuring deviceon improving the internship concept of students in Basic Electronic II course. This is indicated by the specified value of $t_{\text {count }}(=5017)>t_{\text {table }}(=2,365)$ at a confidence level of $95 \%$. In addition, the improvement in understanding internship concept of student in Basic Electronic II course after using the Work Instructions (WI) was in the medium category.

\section{Suggestion}

The advice that can be given is that more research is needed to more accurately measure students' understanding of psychomotor aspects related to electrical meters.

\section{ACKNOWLEDGMENTS}

The researchers express their gratitude to LPPM of Muhammadiyah University of Mataram on the support given to this research so that the research can be smoothly and punctually accomplished.

\section{REFERENCES}

[1] Fitri, L., Suyatna, A., \& Viyanti, V. (2014). Pemanfaatan Media Tik Simulasi Sebagai Substitute Demonstrasi Pada Pembelajaran Alat Ukur. Jurnal Pembelajaran Fisika, 2(2).

[2] Islahudin, I., Khaerani, S., \& Zulkarnain, Z. (2018). Pemanfaatan Laboratorium Virtual Berbasis Ewb (Electronics Workbench) Terhadap Peningkatan Hasil Belajar Fisika Siswa IPA Kelas XII IPA Ma NW Darussalimin Sengkol, Batukliang Lombok Tengah Tahun Pelajaran 2018/2019. ORBITA: Jurnal Kajian, Inovasi dan Aplikasi Pendidikan Fisika, 4(2): 47-51.

[3] Islahudin, I., \& Sabaryati, J. (2018). Pelatihan Pemasangan Lampu Listrik Bersaklar Di Rumah Tangga Menggunakan Konsep EWB (Electronics Workbench) Bagi Siswa SMKN I Batu Kliang Utara Desa Aik Beriq Kecamatan Batu Kliang Utara Kabupaten Lombok Tengah Tahun 2017. SELAPARANG Jurnal Pengabdian Masyarakat Berkemajuan, 1(2): 5-8.

[4] Makiyah, Y. S., Malik, A., Susanti, E., \& Mahmudah, I. R. (2019). Higher Order Thinking Real and Virtual Laboratory (HOTRVL) untuk Meningkatkan Keterampilan Abad Ke-21 Mahasiswa Pendidikan Fisika. DIFFRACTION, 1(1).

[5] Sari, R. M. (2014). Pengaruh Penguasaan Praktik Bank Mini Dan Pengelolaan Laboratorium Bank Mini Terhadap Prestasi Belajar Siswa Kelas Xi Smk Negeri 1 Sukoharjo Tahun Ajaran 2013/2014. 
[6] Wulandari, R. (2019). Pengaruh Penerapan Instruksi Kerja Alat Terhadap Keterampilan Penggunaan Alat Di Laboratorium Fakultas Tarbiyah Dan Keguruan Uin Sunan Ampel Surabaya. Jurnal Pengelolaan Laboratorium Pendidikan, 1(2): 59-63.

[7] Capryani, A., Fahma, F., \& Nur, A. Perancangan Dokumentasi Sistem Manajemen pada Laboratorium Mekatronika UNS Berdasarkan SNI ISO/IEC 17025: 2008. Performa: Media Ilmiah Teknik Industri, 16(1).

[8] Asyhari, A., Irwandani, I., \& Saputra, H. C. (2016). Lembar Kerja Instruksi Konseptual Berbasis PhET: Mengembangkan Bahan Ajar untuk Mengkonstruksi Konsep Siswa Pada Efek Fotolistrik. Jurnal Ilmiah Pendidikan Fisika Al-Biruni, 5(2): 193-204.

[9] Kurnianto, P., \& Dwijanant, P. (2010). Pengembangan Kemampuan Menyimpulkan dan Mengkomunikasikan Konsep Fisika Melalui Kegiatan Praktikum Fisika Sederhana. Jurnal Pendidikan Fisika Indonesia, 6(1).

[10] Sugiono. (2010). Metode Penelitian Kuantitatif Kualitatif dan R \& d. Bandung: CV Alfabeta.

[11] Nurkancana, W., \& Sunartana, P. P. N. (1990). Evaluasi hasil belajar. Surabaya: Usaha Nasional.

[12] Riduwan, M. B. A. (2010). Metode dan teknik menyusun tesis. Bandung: Alfabeta.

[13] Islahudin, I., \& Soeharto, S. (2020). Improving Students' Conceptual Mastery on Digital Circuit Topic Using Electronics Workbench Software. JIPF (Jurnal Ilmu Pendidikan Fisika), 5(1): 8-16.

[14] Islahudin. (2018). Buku Ajar Elektronika Dasar Lanjutan, ISBN:9786237022640. Yogyakarta: Deepublish.

[15] Islahudin, I., \& Nizaar, M. (2017). Pengembangan Sensor Koil Datar 3-D untuk Deteksi Gempa Dini di Wilayah Lombok. Jurnal Nasional Teknik Elektro dan Teknologi Informasi (JNTETI), 6(1): 84-92.

[16] Turnip, B. M., \& Khairani, Z. (2016). Pengaruh Model Pembelajaran ARIAS (Assurance, Relevance, Interest, Assessment, Satisfaction) Terhadap Hasil Belajar Siswa Pada Materi Pokok Listrik Dinamis Di Kelas X SM II SMA Cerdas Murni TP 2014/2015. Jurnal Ikatan Alumni Fisika Universitas Negeri Medan, 2(1): 30-34.

[17] Yuliyanti, E., Hasan, M., \& Syukri, M. (2016). Peningkatan Keterampilan Generik Sains Dan Penguasaan Konsep Melalui Laboratorium Virtual Bebasis Inkuiri. Jurnal Pendidikan Sains Indonesia (Indonesian Journal of Science Education), 4(2): 76-83.

[18] Bayangkari, Y. (2018). Analisis Perbandingan Penggunaan Multisim 11 Simulation dengan Praktikum Langsung terhadap Hasil Belajar Peserta Didik Pada Mata Pelajaran Listrik Dinamis Kelas IX MTs Negeri 2 Bulukumba (Doctoral dissertation, Universitas Islam Negeri Alauddin Makassar).

[19] Sofiani, E. (2011). Pengaruh model inkuiri terbimbing (guided inquiry) terhadap hasil belajar fisika siswa pada konsep listrik dinamis. 